\title{
To study the in-vivo efficacy and safety of AYUSH polyherbal formulation among COVID-19 infected Syrian gold hamsters
}

Divya Kanchibhotla ( $\sim$ operations@ssiar.org)

Sri Sri Institute for Advanced Research https://orcid.org/0000-0002-0760-630X

\section{Saumya Subramanian}

Sri Sri Institute for Advanced Research https://orcid.org/0000-0001-9215-3933

Dr. Hari Venkatesh K.R.

Sriveda Sattva Pvt. Ltd https://orcid.org/0000-0003-1176-3831

Dr. Ravi reddy

Sriveda Sattva Pvt. Ltd https://orcid.org/0000-0002-8582-9656

\section{Research Article}

Keywords: SARS-CoV-2, Syrian Golden Hamster, Ayurveda, COVID-19, NOQ19

Posted Date: September 28th, 2021

DOI: https://doi.org/10.21203/rs.3.rs-936462/v1

License: (a) (i) This work is licensed under a Creative Commons Attribution 4.0 International License. Read Full License 


\section{Abstract}

The COVID-19 pandemic has infected millions of people around the world and the resulting disease burden has challenged the already stressed healthcare systems globally. Amidst the increasing morbidity rate of SARS-CoV-2, the scientific community is vigorously researching possible remedies targeted against the virus. Natural herbs have a great potency to cure infectious diseases and are vastly unexplored. The present study aims to investigate Ayurvedic herbs in a unique polyherbal formulation, NOQ19, against the SARS-CoV-2 virus in an animal model. A total of 19 female Syrian hamsters were infected with the virus cell culture through intranasal route. 4 out of 19 animals were mock controls, 5 were infection controls, 4 were treated with remdesivir and acted as positive controls and remaining 6 were treated with NOQ19. The hamsters were observed to note body weight reduction and adverse events followed by sacrifice on day 4 after inoculation with the virus. The lung pathology and viral load was studied in each hamster. Results showed a significant reduction of $78.2 \%$ in the viral load for the NOQ19 arm, as compared to the infection control. Gross examination of the lung histology of the NOQ19 arm suggested an improvement in edema and congestion compared to the infection control. Also, no adverse events were noticed in NOQ19 hamster group. Therefore, the authors propose NOQ19 formulation as a potential option to be tested further for its efficacy and efficiency against COVID-19.

\section{Introduction}

Time and again the world has been challenged with many diseases. However, the past decade has noticed a significant incidence of multiple zoonotic viral infections crossing over into humans ${ }^{[1]}$ Coronavirus, an infectious viral disease was declared a pandemic on $11^{\text {th }}$ march, 2020 by the World Health Organization. ${ }^{[2]}$ The outbreak of this virus in Wuhan led to a global pandemic, infecting and killing millions due to its high transmission rate, short life-cycle and harmful immuno-pathology . ${ }^{[3]}$ The experience of previous SARS-CoV outbreak propelled the scientific community to design better strategies in curbing the virus. Although, the conventional medicine has been at the forefront of curing and treating COVID-19, it is essential to look at the benefits that the traditional medicine systems have to offer.

${ }^{[4]}$ Current therapeutic strategies include curative measure with repurposed allopathic drugs and prophylactic measures with vaccines. However, there is no known targeted cure for SARS-CoV-2. ${ }^{[5]}$

There exist several research studies on traditional medicines and COVID-19. ${ }^{[6-9]}$

Despite several traditional medicines being proposed for their curative effect on COVID-19, only a few have actually undergone the pathway of drug development. In this manuscript we share a novel polyherbal formulation based on Ayurveda which has been tested in an animal model of COVID-19.

Ayurveda is known to be one of the most ancient systems of medicine. Ayurveda originated from India and has found a wide acceptance globally. ${ }^{[10]}$ The present study focuses on NOQ19, a novel polyherbal 
formulation based on Ayurvedic principles. The formulation consists of potential anti-viral and antiinflammatory herbal extracts such as Ashwagandha, Vasaka, Yashtimadhu and Guduchi. ${ }^{[1-16]}$ In-silico research studies have evaluated the phyto-chemicals from Ashwagandha (Withania somnifera), Guduci (Tinospora cordifolia) and Tulasi (Ocimum sanctum) against main target protease Mpro or or $3 \mathrm{Clpro}$ of SARS CoV-2. ${ }^{[17]}$ It was found that Withanolides and Withanoside from Ashwagandha demonstrate the highest docking against the Mpro target protein. ${ }^{[18-19]}$ Few of the compounds used in NOQ19 contain high amount of alkaloids, flavanoids, tannins and phenols, all of which contribute towards its anti-viral properties. ${ }^{[20]}$ Another herb, well-studied for its anti-viral properties, is Yashtimadhu (Glycyrrhiza glabra). Molecular docking studies have found glycyrrhizin, chief component of Yashtimadhu, as one of the major phyto-chemical to inhibit viral replication. ${ }^{[21-22]}$ Another study conducted a phytochemical analysis and molecular docking of Ashwagandha, Guduchi and Shatavari (Asparagus racemosus) against COVID-19. The results highlighted that several phytoconstituents present in the 3 herbs possess antiviral activity against the spike protein, main Protease and RNA dependent RNA polymerase of the virus. ${ }^{[23]}$ All the previous studies on the Ayurvedic herbs have been in an in-silico model or humans and there is a lack of evidence in an animal model. Hamsters are one of the best models to study the lung pathologies due to the similarities in lung pathologies that develop during the COVID-19 progression between hamsters and humans.

An earlier in vitro study conducted on NOQ19 in Vero E6 cell lines demonstrated good antiviral efficacy of NOQ19 (under publication). The present study aims to evaluate the efficacy and safety of this Ayurvedic polyherbal formulation in a Syrian hamster model. The results of the animal study combined with the human data can support the possibility of adding NOQ19 to the therapeutic options for COVID-19.

\section{Objective}

To evaluate the in vivo therapeutic efficacy of a newly formulated ayurvedic drug, NOQ19, in a SARS CoV2 infected Syrian golden hamster (Mesocricetus auratus) model.

\section{Methodology}

\subsection{Formulation for in vivo studies}

3.1.1 Test material: NOQ19 preparation is a combination of 19 ingredients from 13 ayurvedic herbs : Ashwagandha (Withania somnifera), Bilwa (Aegle marmelos), Yashtimadhu (Glycyrrhiza glabra), Rasna (Pluchea lanceolata), Vasaka (Adhatoda vasica), Pippali (Piper longum), Haridra (Curcuma longa), Patha (Cissampelos pareira), Bhumiamla (Phyllanthus fraternus), Bhunimba (Andrographis paniculata), Saptaparna (Alstonia scholaris), Tulasi (Ocimum sanctum) and Guduci (Tinospora cordifolia). Some of herbs were used only as a powder while Ashwagandha (Withania somnifera), Yashtimadhu (Glycyrrhiza glabra), Vasaka (Adhatoda vasica), Bhumiamla (Phyllanthus fraternus), Bhunimba (Andrographis paniculata),and Guduci (Tinospora cordifolia) were used as both powder and extract. 
NOQ 19 was procured from Sriveda Sattva Pvt Ltd, Bangalore (Sri Sri Tattva). The drug was licensed by Ministry of AYUSH, Govt. of India with the license number- AUS782. It was supplied in the powdered form and stored at $4 \mathrm{oC}$ until further use.

All the herbs \& herbal extracts which constituted NOQ19 were subjected for quality control Analysis and after the approval process, ingredients were issued for production as fine powders. All the ingredients were blended with excipients followed by granulation and drying.

The animal study was conducted at Foundation for Neglected Disease Research (FNDR) in the BSL-3 laboratory. All the ethical guidelines with respect to the animal study were met in accordance.

\subsection{Animal Model: Syrian Golden Hamsters}

6-8 weeks old female Syrian golden hamsters (Tata Memorial Advanced Center for Treatment, Research \& Education in Cancer (ACTREC), (65/PO/ReBiBt/S/99/CPCSEA)) were used in the study. Body weight determination and other general veterinary examination was performed for the hamsters at the time of enrollment. Only healthy animals weighing around 80-100 grams were included in the study.

A total of 19 hamsters were enrolled in each of the 4 groups, each group consisting of 4-6 animals.

\subsection{Animal care:}

All the animals were kept in individually ventilated cases to familiarize them with the environment(Citizen Industries, CRB-48-SS,V7E). The room conditions were maintained as $18^{\circ} \mathrm{C}-25^{\circ} \mathrm{C}$ temperature, $30 \%-70 \%$ humidity, 12-hour light and 12-hour dark. The animals were identified by body markings and therefore maintained in different groups. Feed and RO water were provided to the animals ad libitum.

\subsection{Animal ethics statement}


The study plan to evaluate the antiviral activity in a COVID -19 infection model in hamsters was recommended by FNDR's Institutional Animal Ethics Committee (IAEC), Registration Number 2082/PO/Rc/S/19/CPCSEA, on 21st December 2021 through Form-B proposal number FNDRFB-045. The same was approved by the Committee for the Purpose of Control and Supervision of Experiments on Animals (CPCSEA), India. All the ethical practices as laid down in the CPCSEA guidelines for animal care were followed during the conduct of the study. Further, procedures used in this study plan were designed to conform to the accepted practices and to minimize or avoid risk of causing pain, distress or discomfort to the animals.

3.5 Viral Cell culture for infection:

The SARS-CoV-2 viral isolate was obtained by BEl resources managed by ATCC. Isolate USAWA1/2020 was isolated from an oropharyngeal swab from a patient with a respiratory illness who had recently returned from travel to the affected region of China and developed clinical disease (COVID-19) in January 2020 in Washington, USA. ${ }^{[24]}$

\subsubsection{Study Design}

19 female Syrian golden hamsters, 6-8 weeks of age, were taken for the study. Among the 19 hamsters, 4 hamsters were not infected with the virus and were labeled as mock control, 5 hamsters were infected with the virus and received placebo intervention and were labeled as disease control, 4 other hamsters were infected with the virus and received the remdesivir intervention and were labeled as positive control, while remaining 6 hamsters were infected with the virus and received test intervention NOQ19 and were labeled as test. Hamsters were anesthetized with ketamine $(150 \mathrm{mg} / \mathrm{kg})$ and xylazine $(10 \mathrm{mg} / \mathrm{kg})$ by intraperitoneal injection and inoculated with the virus intranasally with $100 \mu \mathrm{L}$ of DMEM containing $1 \times$ $106 \mathrm{PFU} / \mathrm{ml}$ virus. Hence, the total concentration of virus administered per hamster was $1 \times 105 \mathrm{PFU}$. The hamsters received respective intervention (Ayurvedic formulation or remdesivir) 24 hours post infection. The respective intervention was also given intraperitoneally. For the remdesiver control, a dose of $15 \mathrm{mg} / \mathrm{kg}$, for 3 days daily, 1 DPI, 2DPI \& 3 DPI was given. For the NOQ19 intervention, $1000 \mathrm{mg} / \mathrm{kg}$ in saline was given for 3 days daily, 1 DPI, 2DPI \& 3 DPI. After 3 days of intervention, the animals were euthanized and sacrificed for viral load estimation and gross pathological examination.

\subsection{Viral Load estimation}

After sacrificing the hamsters, the following procedure was carried out for viral load estimation and gross pathological examination 
3.7.1 Sample Preparation: The whole lung was aseptically removed from the sacrificed animal. Changes in the body weight before and after clinical administration were noticed. After gross pathological examination, the lung was homogenized for about 15- 30 seconds using Pro 200 homogenizer (Pro Scientific Inc. Monroe, CT. USA) in a final volume of $2 \mathrm{ml}$ of sterile PBS in Wheaton Teflon-Glass tissue grinders (catalogue no. W012576). The homogenized tissue was centrifuged at $4000 \mathrm{rpm}$ for 10 minutes to remove the debris and the supernatant was collected. Volume of the supernatant was measured.

3.7.2 Vero E6 cells preparation: A 96 well plate was coated with 200ul containing approx. 30,000 Vero E6 cells in DMEM media with $10 \%$ FBS. The plate was incubated overnight (12-18 h) at $37^{\circ} \mathrm{C}$ to achieve a Vero E6 cell monolayer.

3.7.3 Sample plating: $50 \mu$ l of samples (lung tissue) were serially diluted (10-fold) in DMEM and each dilution was plated in a different well with the pre-formed Vero E6 cell monolayer and incubated for $1 \mathrm{~h}$ at $37^{\circ} \mathrm{C}$ in a $5 \% \mathrm{CO} 2$ incubator with shaking at every 15 minutes.

3.7.4 Overlay: After 1 hour incubation, the samples were removed from the well. The cell monolayer was then again overlaid with $200 \mu \mathrm{L}$ of DMEM: CMC and incubated for 3 days at $37^{\circ} \mathrm{C}$ in $5 \%$ CO2. DMEM: CMC was prepared by mixing equal volume of DMEM $(2 x)$ and $2 \%$ carboxymethylcellulose.

3.7.5 Fixing. After the 3-day incubation, the DMEM-CMC overlay was gently removed with a pipette, the cells were washed twice with PBS and then fixed by adding $200 \mu \mathrm{L}$ of $4 \%$ formaldehyde to each well. The plate was incubated at room temperature for 30 minutes after which formaldehyde was removed from the wells and dispensed in an appropriate hazardous waste container.

3.7.6 Staining: $100 \mu \mathrm{L}$ of $0.05 \%(\mathrm{w} / \mathrm{v})$ crystal violet in $20 \%$ methanol was added to each well and the plate was incubated for 30 minutes. Crystal violet was removed with a pipette and cells were washed twice with distilled water or until the excess crystal violet had been removed, and the plaques were easily visualized.

3.7.7 Counting: The plaques (PFU) were counted for the dilution at which clear readable counts were noticed and were determined as PFU per $\mathrm{ml}$. The PFU per lung was calculated using the dilution factor and PFU per ml. Cell only control was used as a negative control.

3.7.8 Viral loads in the lung were compared for the test and controls groups by a oneway analysis of variance (ANOVA) followed by Dunnett's multiple comparison using GraphPad Prism software (Version 9).

\section{Results}

Therapeutic use of intraperitoneal instillation of Ayurvedic formulation prevents SARS-CoV-2 viral load and associated gross clinical parameters

\subsection{Gross pathological examination}


Gross pathological observations demonstrated normal hamster lungs in the non-infected group. The infected untreated group demonstrated severe edema and inflammation in all lobes. (Fig 1) The infected untreated group also had diffused multi-focal hemorrhage and congestion. The infected remdesivir group showed mild edema and multi-focal congestions in the lungs (Fig 1). While the NOQ19 (NF-2) group showed improvement in lung edema, hemorrhage and congestion as compared to the untreated group.

Also, the uninfected mock control group hamsters showed an increase in their body weights during the study period. While the infected treatment groups showed a reduction in the body weights. NOQ19 treated hamsters showed less body weight reduction when compared to the infection control.(Fig 2)

\subsection{Viral load estimation}

The test item NF-2 (NOQ19) showed significant antiviral activity at $1000 \mathrm{mg} / \mathrm{kg}$ BID dosing in comparison to the untreated control group. Compared to the infected untreated group, the reduction of viral load in NOQ19 group was $78.2 \%$. 


\begin{tabular}{|c|c|c|c|c|c|c|c|c|}
\hline \multirow[t]{2}{*}{ Group } & \multirow[t]{2}{*}{ Dpi } & \multirow{2}{*}{$\begin{array}{l}\text { Animal } \\
\text { Number }\end{array}$} & \multicolumn{3}{|c|}{ Number of plaques } & \multirow[t]{2}{*}{$\mathrm{PFU} / \mathrm{ml}$} & \multirow{2}{*}{$\begin{array}{l}\text { Log } \\
\text { Reduction }\end{array}$} & \multirow{2}{*}{$\begin{array}{l}\text { Percentage } \\
\text { Reduction }\end{array}$} \\
\hline & & & 1 & 2 & Average & & & \\
\hline \multirow{4}{*}{$\begin{array}{l}\text { Mock } \\
\text { Infection }\end{array}$} & \multirow[t]{4}{*}{4} & 1 & 0 & 0 & 0 & 0 & 0 & \multirow[t]{4}{*}{0} \\
\hline & & 2 & 0 & 0 & 0 & 0 & 0 & \\
\hline & & 3 & 0 & 0 & 0 & 0 & 0 & \\
\hline & & 4 & 0 & 0 & 0 & 0 & 0 & \\
\hline \multirow{5}{*}{$\begin{array}{l}\text { Infection } \\
\text { Control }\end{array}$} & \multirow[t]{5}{*}{5} & 5 & 19 & 18 & 18.5 & $37 * 10^{5}$ & \multirow[t]{5}{*}{ NA } & \multirow[t]{5}{*}{ NA } \\
\hline & & 6 & 18 & 14 & 16 & $32 * 10^{5}$ & & \\
\hline & & 7 & 22 & 25 & 23.5 & $47 * 10^{5}$ & & \\
\hline & & 8 & 16 & 18 & 17 & $34^{*} 10^{5}$ & & \\
\hline & & 9 & 21 & 19 & 20 & $40 * 10^{5}$ & & \\
\hline \multirow[t]{4}{*}{ Remdesivir } & \multirow[t]{4}{*}{4} & 10 & 5 & 8 & 6.5 & $1.3 * 10^{5}$ & \multirow[t]{4}{*}{1.34} & \multirow[t]{4}{*}{99.5} \\
\hline & & 11 & 12 & 10 & 11 & $2.2 * 10^{5}$ & & \\
\hline & & 12 & 9 & 11 & 10 & $2 * 10^{5}$ & & \\
\hline & & 13 & 6 & 9 & 7.5 & $1.5^{\star} 10^{5}$ & & \\
\hline \multirow[t]{6}{*}{ NOQ19 } & \multirow[t]{6}{*}{6} & 14 & 8 & 4 & 6 & $12 * 10^{5}$ & \multirow[t]{6}{*}{0.66} & \multirow[t]{6}{*}{78.2} \\
\hline & & 15 & 15 & 18 & 16.5 & $3.3 * 10^{5}$ & & \\
\hline & & 16 & 5 & 4 & 4.5 & $9 * 10^{5}$ & & \\
\hline & & 17 & 17 & 19 & 18 & $3.6 * 10^{5}$ & & \\
\hline & & 18 & 6 & 9 & 7.5 & $15^{\star} 10^{5}$ & & \\
\hline & & 19 & 10 & 6 & 8 & $16 * 10^{5}$ & & \\
\hline
\end{tabular}

\section{Discussion}

With the intense vaccination efforts, the COVID-19 cases across the globe have reduced ${ }^{[25]}$ Nevertheless, emergence of mutant strains, high transmission rates and severity of the SARS-CoV-2 disease pose a constant threat to the public. ${ }^{[26]}$ Existing solutions include repurposing already existing drugs to curb the disease symptoms. The solution requires an anti-viral drug targeted against the virus for inhibition of viral 
replication. The present study investigates the efficacy of a polyherbal formulation, NOQ19 in Syrian golden hamster model. The study results demonstrated more than $78 \%$ reduction in viral load when treated with NOQ19. A similar study by Jan et al reported that a few chinese traditional medicines demonstrated significant anti-viral properties against SARS-CoV-2 in a Syrian hamster model. The study reported that two herbs, Mentha haplocalyx and Perilla frutescens, significantly reduced the viral load. ${ }^{[27]}$ Ayurveda, an ancient Indian science also cites many herbal formulations that have potential antiviral benefits. Infact several Ayurvedic approaches were recommended in the past for management of COVID19. ${ }^{[28]}$ Another study demonstrated that the use of two intra-nasal Ayurvedic oil formulations; Anu tailya and Til tailya; significantly reduced the SARS-CoV-2 viral load in a hamster model. ${ }^{[29]}$

The current study evaluated the therapeutic efficacy of an Ayurvedic polyherbal formulation in a hamster model against SARS-CoV-2. Hamster models are considered most suitable animal model for SARS-CoV-2 infection and studying the therapeutic role of drugs. This is because, post infection with SARS-CoV-2, the animal shows rapid breathing, alveolar damage, edema, extensive apoptosis and rapid weight loss. [30] One important finding of the study was lesser weight loss in the NOQ19 treated animal group with respect to other groups. Traditionally Ashwagandha has been used for weight loss management. Among the multiple health benefits of Ashwagandha, it is known for its adaptogenic properties. Therefore, the herb minimizes the weight loss/weight gain incurred due to environmental stress. ${ }^{[31]}$ Presence of Ashwagandha in NOQ19 may provide a justification for the present observation. As noted in the infection mock-control of hamsters, intranasal application of SARS-CoV-2 produces severe haemorrhage, congestion, edema and lung pathologies. However, it was noticed that among the NOQ19 treated group, the pathological severity was reduced. This could be secondary to the reduction in viral replication caused by Glycyrrhizin component of Yashtimadhu (Glycyrrhiza glabra). ${ }^{[32-34]}$ Another possibility for reduced congestion and haemorrhage could be the anti-thrombotic properties of Bhunimba (Andrographis paniculata) which prevents blood clotting. ${ }^{[35]}$ Few other ingredients like Haridra (Curcuma longa), Bhumiamla (Phyllanthus fraternus) and Vasaka (Adhatoda vasica) are known for their antiinflammatory properties, and can assist in reducing the symptoms of immune response like edema and pneumonitis. ${ }^{[36-38]}$ Also, none of the hamsters in NOQ19 treatment group reported any adverse events after the NOQ19 inoculation. This demonstrated the safety of the NOQ19 among the hamster model. The current study, is a pre-clinical study and focuses on the efficacy of the formulation in an animal model. Further phase 1 and phase 2 clinical trials can evaluate the safety of the NOQ19 in human beings.

\section{Conclusion}

There is a great need for safe and effective options to combat the COVID-19 pandemic. Several traditional approaches including Ayurveda have been proposed for the symptomatic and therapeutic management of COVID-19. This study determines the efficacy of a polyherbal Ayurvedic formulation called NOQ19, in a Syrian hamster model. The hamsters treated with NOQ19 reported a $78.2 \%$ reduction 
in viral load and improved lung pathology after 3 days of treatment. The in-vivo efficacy of the drug provides an incentive to further explore the therapeutic benefits of this drug in humans.

\section{Declarations}

\section{Acknowledgments}

We would like to acknowledge Dr. Rudra Murthy G.R., Foundation for Neglected Disease Research (FNDR), Bengaluru for conducting the experiment in their facility. We would also like to acknowledge Dr Somya Ramrakhyani for language edits.

\section{Funding}

We would like to thank Cooper Family Foundation, Australia for providing us the funding for this in vivo study.

Competing interests: The authors declare no competing interests.

\section{Abbreviations}

1. SARS-CoV-2: Severe acute respiratory syndrome- Coronavirus

2. COVID-19: Corona virus disease-2019

\section{References}

[1] Mack A, Choffnes ER, Hamburg MA, Relman DA, editors. Microbial evolution and co-adaptation: a tribute to the life and scientific legacies of Joshua Lederberg: workshop summary. National Academies Press; 2009 May 10.

[2] Coronavirus disease (COVID-19) pandemic. World Health Organization, https://www.who.int/emergencies/diseases/novel-coronavirus-2019? gclid=Cj0KCQjwqKuKBhCxARIsACf4XuEYfnl-1 eclOzr4xx3p32TL6_zI2Z6VPSqsJE1SPKRcG93P5zKiMAaAhc7EALw_wcB. [accessed on $15^{\text {th }}$ September, 2021] [3] Hu B, Guo H, Zhou P, Shi ZL. Characteristics of SARS-CoV-2 and COVID-19. Nat. Rev. Microbiol. 2021;19(3):141-54. 
[4] Tillu G, Chaturvedi S, Chopra A, Patwardhan B. Public health approach of ayurveda and yoga for COVID-19 prophylaxis. J. Altern. Complement. Med. 2020;26(5):360-4.

[5] Yimer G, Ekuadzi E, Fasinu P, de Melo AC, Pillai G. Traditional medicines for COVID-19: Perspectives from clinical pharmacologists. Br. J. Clin. Pharmacol. 2021;87(9):3455-8.

[6] Luo L, Jiang J, Wang C, Fitzgerald M, Hu W, Zhou Y, et al. Analysis on herbal medicines utilized for treatment of COVID-19. Acta Pharm. Sin. B. 2020;10(7):1192-204.

[7] Randeepraj VR, Madhuri KM, Jogi PJ, Gujju EG, Sanaboina AS, Bolem OB. Herbs/Traditional Medicines Used In Covid-19. Int. j. indig. herbs drugs. 2020;30:31-6.

[8] Hensel A, Bauer R, Heinrich M, Spiegler V, Kayser O, Hempel G et al. Challenges at the Time of COVID19: Opportunities and Innovations in Antivirals from Nature. Planta Med. 2020;86(10):659-64.

[9] Mirzaie A, Halaji M, Dehkordi FS, Ranjbar R, Noorbazargan H. A narrative literature review on traditional medicine options for treatment of corona virus disease 2019 (COVID-19). Complement. Ther. Clin. Pract. 2020;40:101214.

[10] Parasuraman S, Thing GS, Dhanaraj SA. Polyherbal formulation: Concept of ayurveda. Pharmacogn. Rev. 2014;8(16):73.

[11] Gupta GL, Rana AC. Withania somnifera (Ashwagandha): a review. Pharmacogn. Rev.2007;1(1):12936

[12] Pant M, Ambwani T, Umapathi V. Antiviral activity of Ashwagandha extract on infectious bursal disease virus replication. Indian J Sci Technol. 2012;5(5):2750-1.

[13] Anagha K, Manasi D, Priya L, Meera M. Scope of Glycyrrhiza glabra (Yashtimadhu) as an antiviral agent: a review. Int. J. Curr. Microbiol. App. Sci. 2014;3(12):657-65.

[14] Kumar S, Dora BB. A Critical Appraisal on Phytochemical Constituents and Therapeutic Effect of Yashtimadhu (Glycyrrhiza glabra). Research \& Reviews: JMST. 2017;6(3):6-10.

[15] Rawat N, Roushan R. Guduchi: A potential drug in Ayurveda. World J Pharm Res. 2018;7:355-61.

[16] Routh T, Chowdhury BR, Mandal D, Basak S, Roy R, Majumdar P. Extraction Encapsulation and Development of Functional Food of Some Selected Indian Antiviral Herbs. IJISRT. 2021;6(8):789-93

[17] Shree P, Mishra P, Selvaraj C, Singh SK, Chaube R, Garg N, et al. Targeting COVID-19 (SARS-CoV-2) main protease through active phytochemicals of ayurvedic medicinal plants-Withania somnifera (Ashwagandha), Tinospora cordifolia (Giloy) and Ocimum sanctum (Tulsi)-a molecular docking study. J Biomol Struc. Dyn 2020;26:1-4. 
[18] Tripathi MK, Singh P, Sharma S, Singh TP, Ethayathulla AS, Kaur P. Identification of bioactive molecule from Withania somnifera (Ashwagandha) as SARS-CoV-2 main protease inhibitor. J Biomol Struct Dyn 2020;6:1-4.

[19] Khanal P, Chikhale R, Dey YN, Pasha I, Chand S, Gurav N et al. Withanolides from Withania somnifera as an immunity booster and their therapeutic options against COVID-19. J Biomol Struct Dyn 2020;26:1-4.

[20] Ben-Shabat S, Yarmolinsky L, Porat D, Dahan A. Antiviral effect of phytochemicals from medicinal plants: Applications and drug delivery strategies. Drug Deliv Transl Res. 2020;10(2):354-67.

[21] Damle M. Glycyrrhiza glabra (Liquorice)-a potent medicinal herb. Int J Herb Med 2014;2(2):132-6.

[22] Sinha SK, Prasad SK, Islam MA, Gurav SS, Patil RB, AlFaris NA et al. Identification of bioactive compounds from Glycyrrhiza glabra as possible inhibitor of SARS-CoV-2 spike glycoprotein and nonstructural protein-15: a pharmacoinformatics study. J Biomol Struct Dyn 2020:1-5.

[23] Borse S, Joshi M, Saggam A, Bhat V, Walia S, Marathe A, et al. Ayurveda botanicals in COVID-19 management: An in silico multi-target approach. Plos one. 2021 Jun 11;16(6):e0248479.

[24] BEl resources. https://www.beiresources.org/Catalog/animalviruses/NR-52281.aspx. [accessed on $8^{\text {th }}$ September, 2021]

[25] Coronavirus disease (COVID-19): Vaccines. https://www.who.int/news-room/q-a-detail/coronavirusdisease-(covid-19) vaccines?adgroupsurvey $=\{$ adgroupsurvey $\}$ \&clid=Cj0KCQjwqKuKBhCxARIsACf XuFeGguiZtHn_9Q5sKXrbHJIBO_eQOA_DJZEXPLvHpJOxpMMxb84slaAikqEALw_wcB [accessed on $21^{\text {st }}$ September, 2021]

[26] Verity R, Okell LC, Dorigatti I, Winskill P, Whittaker C, Imai N, et al. Estimates of the severity of coronavirus disease 2019: a model-based analysis. Lancet Infect Dis. 2020 ;20(6):669-77.

[27] Jan JT, Cheng TJ, Juang YP, Ma HH, Wu YT, Yang WB, et al. Identification of existing pharmaceuticals and herbal medicines as inhibitors of SARS-CoV-2 infection. Proceedings of the National Academy of Sciences. 2021;118(5):1-8

[28] Ahmad S, Zahiruddin S, Parveen B, Basist P, Parveen A, Parveen R, et al. Indian medicinal plants and formulations and their potential against COVID-19-preclinical and clinical research. Front. Pharmacol. $2021 ; 11: 2470$.

[29] Rizvi ZA, Tripathy MR, Sharma N, Goswami S, Srikanth N, Sastry JL, et al. Effect of prophylactic use of intra-nasal oil formulations in the hamster model of Covid-19. bioRxiv. 2021.

[30] Takayama K. In vitro and animal models for SARS-CoV-2 research. Trends Pharmacol. Sci. 2020;41(8):513-7. 
[31] Umadevi M, Rajeswari R, Rahale CS, Selvavenkadesh S, Pushpa R, Kumar KS, et al. Traditional and medicinal uses of Withania somnifera. J. Pharm. Innov.. 2012;1(9, Part A):102.

[32] Gowda P, Patrick S, Joshi SD, Kumawat RK, Sen E. Glycyrrhizin prevents SARS-CoV-2 S1 and Orf3a induced high mobility group box 1 (HMGB1) release and inhibits viral replication. Cytokine 2021;142:155496

[33] Fuzimoto AD, Isidoro $C$. The antiviral and coronavirus-host protein pathways inhibiting properties of herbs and natural compounds-Additional weapons in the fight against the COVID-19 pandemic? J Tradit Complement Med 2020;10(4):405-19.

[34] Hoever G, Baltina L, Michaelis M, Kondratenko R, Baltina L, Tolstikov GA, et al. Antiviral activity of glycyrrhizic acid derivatives against SARS- coronavirus. J Med Chem 2005;48(4):1256-9.

[35] Mishra SK, Sangwan NS, Sangwan RS. Andrographis paniculata (Kalmegh): A review. Pharmacogn Rev 2007;1(2):283-98.

[36] Khanal $\mathrm{H}$, Khanal $\mathrm{U}$, Koirala J. Medicinal plant vasaka could be a therapeutic option for the management of COVID-19 symptoms. J Med Plants 2020;8(5):44-8.

[37] Liu S, Wei W, Shi K, Cao X, Zhou M, Liu Z. In vitro and in vivo anti-hepatitis B virus activities of the lignan niranthin isolated from Phyllanthus niruri L. J Ethnopharmacol 2014;155(2):1061-7.

[38] Panda AK, Dixit AK, Rout S, Mishra B, Purad UV, Kar S. Ayurveda practitioners consensus to develop strategies for prevention and treatment of Corona Virus Disease (COVID-19). J. Ayurveda Integr. Med.2020;5(1):98-106.

\section{Figures}




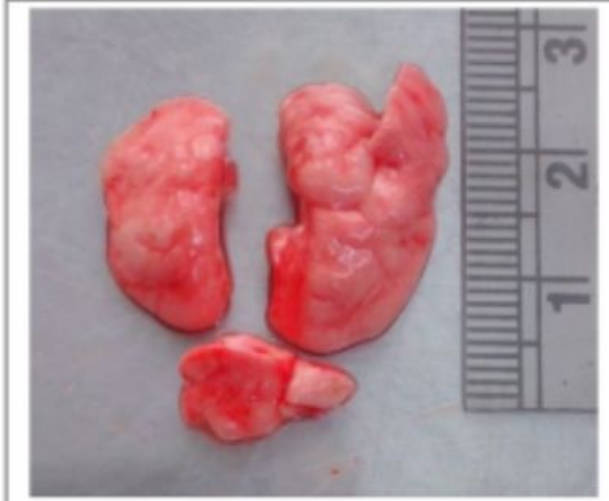

Mock Control

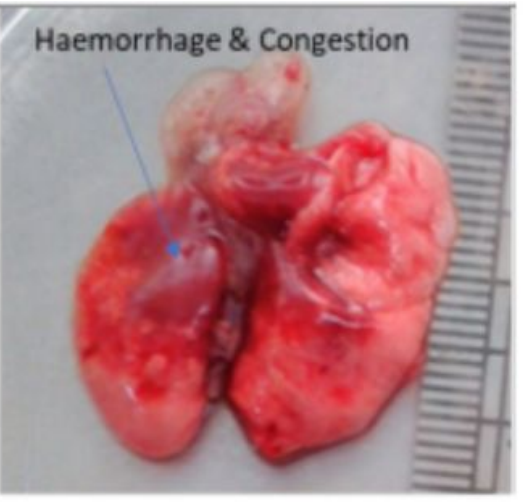

Infection Control Edematous lung

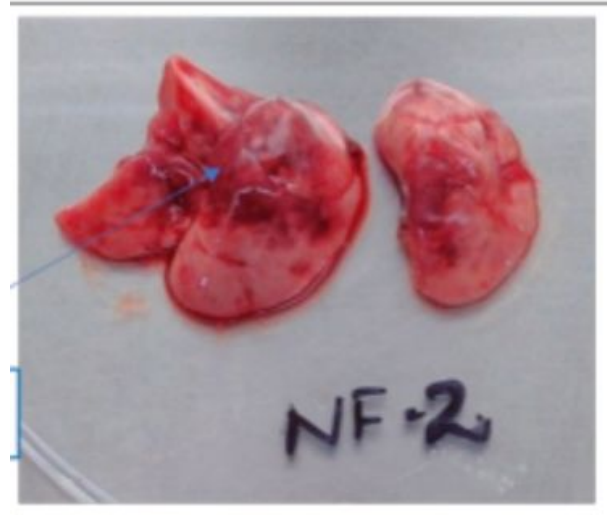

NF-2

\section{Figure 1}

Representative gross images of the lungs from different study groups

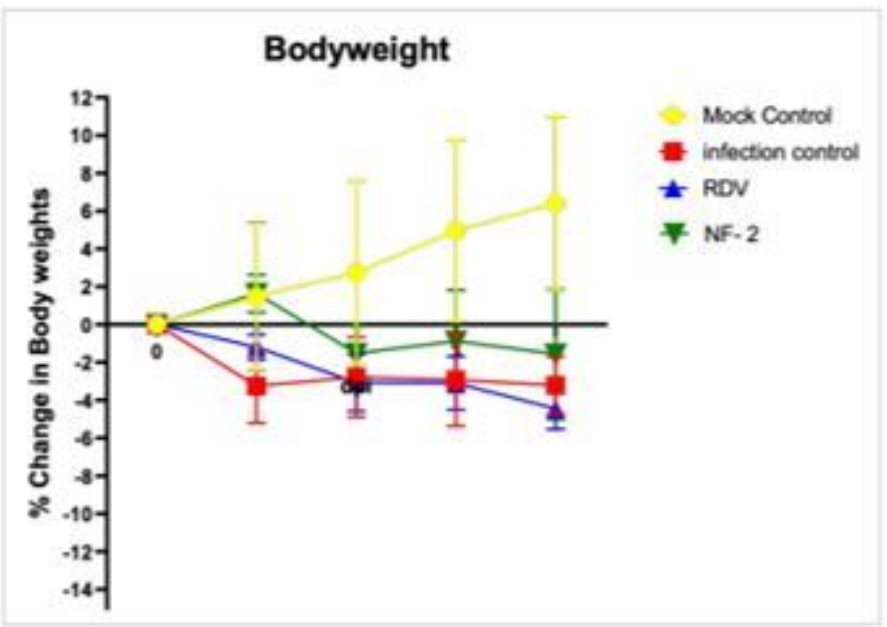

Figure 2

Body Weight Reduction in different group of hamsters 
- Infection Control

Remdesivir (RDV)

NF-2

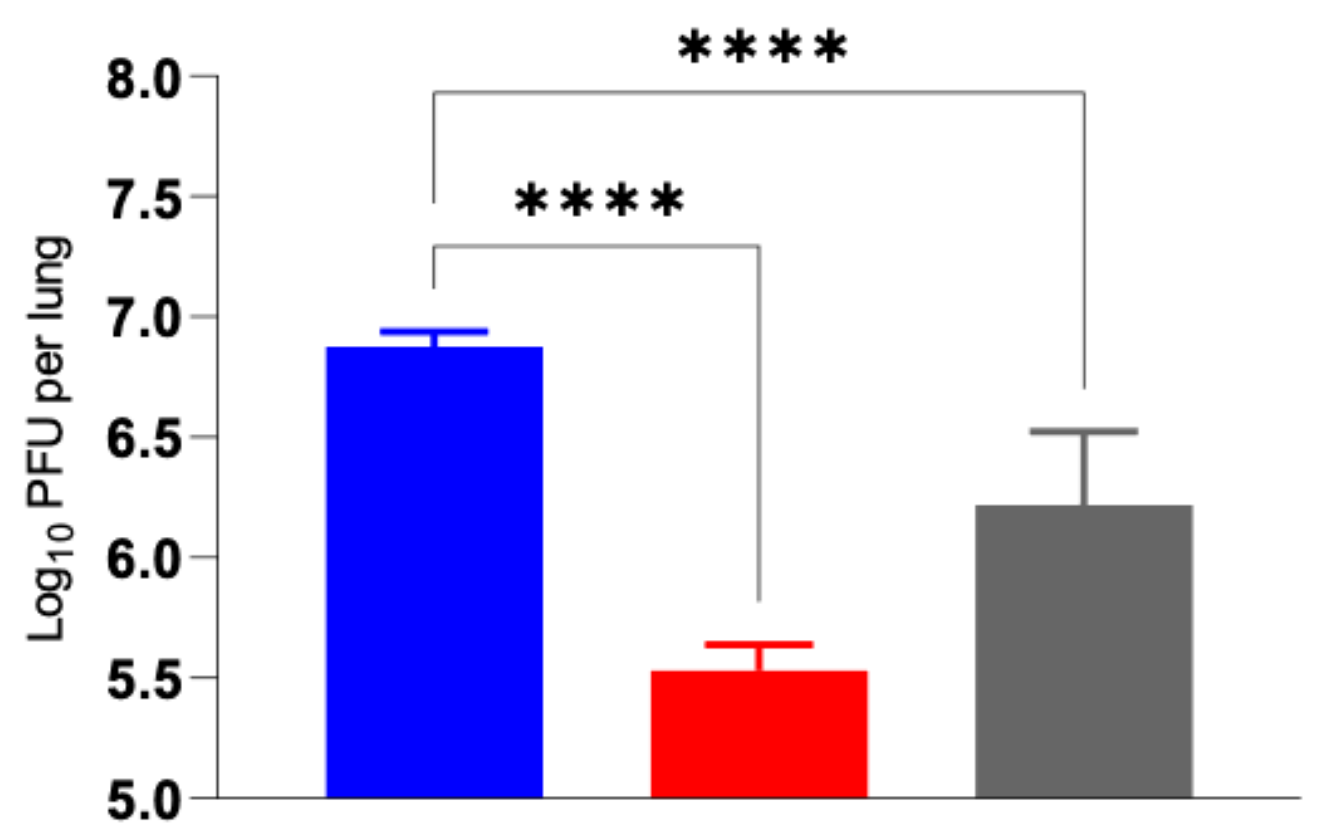

Figure 3

Log of Viral load reduction in the positive control and NOQ19 group from the infection untreated group 